MATEC Web of Conferences 9, 01003 (2013)

DOI: $10.1051 /$ matecconf/20130901003

(C) Owned by the authors, published by EDP Sciences, 2013

\title{
Comparative analysis of façade regulations in the Nordic countries
}

\author{
Michael Strömgren ${ }^{1}$, Joakim Albrektsson ${ }^{1}$, Anders Johansson ${ }^{2}$ and Erik \\ Almgren $^{3}$ \\ ${ }^{1}$ SP Technical Research Institute of Sweden, Borås, Sweden \\ ${ }^{2}$ The National Board of Housing, Building and Planning (Boverket) Karlskrona, Sweden \\ ${ }^{3}$ Bengt Dahlgren, Fire \& Risk Malmö, Sweden
}

\begin{abstract}
This paper presents a comparison of Nordic fire safety requirements of facades. A reference building was chosen as a four-story residential building. The requirements were analysed with focus on what fire safety objectives they represent, and what type of pre-accepted solutions that were used. The results reveal large differences in the Nordic building regulations concerning façades. The differences occur both with regards to performance objectives, criteria and acceptable solutions. Current European methods are not sufficient to characterise the requirements needed for fire safety of facades. There is a need to develop new common verification methods, as well as better data and research, to improve requirements and to reach conformity.
\end{abstract}

\section{INTRODUCTION/BACKGROUND}

Fire safety in facades has been under the spotlight in recent years due to several significant fires. Also, new façade designs challenge the traditional pre-accepted fire safety solutions and therefore call for new verification methods. In the European perspective, several countries have used large-scale methods to evaluate facades, whereas the European standardization has not yet agreed on a common verification method. This paper demonstrates the lack of commonly agreed verification methods by comparing the building legislation and regulations in the Nordic countries. The Nordic comparison is interesting because of the many similarities, with yet a great spread in resulting regulations. In this context, current practice in Sweden is discussed.

The Nordic countries share a history of collaboration for the area of building regulations. This goes back to work done by NKB (Nordic Committee on Building Regulations) that started in the sixties. However, there are still large differences in the regulations. These differences can present a barrier of trade for products and services. The construction products directive (CPD), and now the construction products regulation [1], CPR, and the resulting European harmonization of testing and classes for fire safety has mitigated some of these differences. However, the testing and classification methods do not cover all fire safety aspects relevant to facades. It would be reasonable to assume that climate, occupant behaviour etc. would be quite similar in the Nordic countries, which also would give ground for similar regulation of fire safety of facades (and other areas). By identifying differences and analysing these from a fire risk perspective, further steps may be taken to adequately regulate fire safety of facades.

In 2008, another Nordic project analysed differences in classifications in the Nordic countries but no deeper studies of facades were conducts. The conclusions in the final report still revealed that there

This is an Open Access article distributed under the terms of the Creative Commons Attribution License 2.0, which permits unrestricted use, distribution, and reproduction in any medium, provided the original work is properly cited. 


\section{MATEC Web of Conferences}

were large differences in façade regulations, and that there was a need for a common European method in order to harmonize requirements. Also for many other product areas and parts of the building systems, differences were identified [2].

\section{METHOD}

The method used in this study has been to identify the relevant clauses in the building regulations of the Nordic countries (Iceland was excluded). The most relevant characteristics or objectives in the regulations that were subject to requirements were identified. The Nordic regulations concerning fire safety of facades were classified according to the identified objectives. Some aspects, such as fire spread between buildings due to radiation were not considered in this study.

1. Identification of characteristics for façade fire safety requirements

2. Classification of the Nordic regulations regarding facades

3. Analysis

4. Comparison with EU legislation and test methods.

\section{BUILDING OF REFERENCE}

To identify the relevant requirements for the comparative analysis, a building of reference was chosen. The building of reference was chosen to be four stories tall in order to represent a normal Nordic building. The requirements for four story buildings are in many aspects representative also for buildings between three and eight stories, due to the construction of the requirements. However, some variations exist. The building was fitted with one stair case. The other possible escape route would be rescue by fire brigade with ladders from windows.

\section{ELEMENTS FOR COMPARISON}

The countries that were included for the regulatory analysis were Denmark, Finland, Norway and Sweden. Iceland was not included but it should be noted that the Icelandic building regulations usually are similar to other Nordic countries building regulations.

Based on the functional requirements present in the building regulation, the following performance objectives were identified, as seen in Table 1.

The analysis primarily focused on the pre-accepted solutions, so called deemed-to-satisfy solutions. In all countries part of the study it may also be possible to use alternative approaches, verifying the design alternatives by fire safety engineering methods.

\section{RESULTS}

The comparison of Nordic building regulations reveals that there are quite large differences for all of the six objectives. Main differences that should be noted are connected to how performance objectives are expressed. Some countries express requirements that are related to the material properties or function of individual components. Others express main functional objectives for the whole external wall and façade. However, uncertainties exist regarding the verification methods and how the assessment of the performance in practice of a façade and external wall should be evaluated. The tables below list summaries of the requirements in each country. Some simplification has been done, and in some cases requirements for other building types is given for informative reasons. 
$1^{\text {st }}$ International Seminar for Fire Safety of Facades, Paris (France), 2013

Table 1. The following objectives, performance requirements and criteria were compared.

\begin{tabular}{|l|l|l|}
\hline Objectives & $\begin{array}{l}\text { Example of performance } \\
\text { requirement or criteria }\end{array}$ & $\begin{array}{l}\text { Example of acceptable } \\
\text { solutions }\end{array}$ \\
\hline $\begin{array}{l}\text { 1. Protection against fire } \\
\text { spread along the façade }\end{array}$ & $\begin{array}{l}\text { Minimum reaction } \\
\text { to fire class }\end{array}$ & $\begin{array}{l}\text { Minimum rating of B-s1,d0, or } \\
\text { fulfilling testing criteria by SP } \\
\text { Fire 105 (see note below) }\end{array}$ \\
\hline $\begin{array}{l}\text { 2. Maintaining the function of } \\
\text { the fire compartmentation }\end{array}$ & $\begin{array}{l}\text { Minimum fire resistance } \\
\text { rating for parts of, or the whole, } \\
\text { extern wall }\end{array}$ & $\begin{array}{l}\text { Fire stops at each floor level } \\
\text { of at least EI 30 rating }\end{array}$ \\
\hline $\begin{array}{l}\text { 3. Protection against } \\
\text { falling objects }\end{array}$ & $\begin{array}{l}\text { Fulfilling testing criteria using } \\
\text { a full scale façade method }\end{array}$ & $\begin{array}{l}\text { Fulfilling testing criteria by SP } \\
\text { Fire 105 }\end{array}$ \\
\hline $\begin{array}{l}\text { 4. Reaction to fire } \\
\text { requirements for } \\
\text { components in the } \\
\text { external wall }\end{array}$ & $\begin{array}{l}\text { Minimum reaction to } \\
\text { fire class for components }\end{array}$ & $\begin{array}{l}\text { Non-combustible material, A2- } \\
\text { s1,d0, for insulation material } \\
\text { and other components } \\
\text { in the external wall }\end{array}$ \\
\hline $\begin{array}{l}\text { 5. Reaction to fire } \\
\text { requirements for the load } \\
\text { - bearing construction in the } \\
\text { external wall }\end{array}$ & $\begin{array}{l}\text { Minimum reaction to fire class } \\
\text { for load-bearing elements }\end{array}$ & $\begin{array}{l}\text { Non-combustible material, A2- } \\
\text { s1,d0, for insulation material } \\
\text { and other components } \\
\text { in the external wall }\end{array}$ \\
\hline $\begin{array}{l}\text { 6. Protection against fire } \\
\text { spread between windows }\end{array}$ & $\begin{array}{l}\text { Minimum vertical separation } \\
\text { distance between windows }\end{array}$ & \begin{tabular}{l}
1,2 m separation distance \\
\hline
\end{tabular}
\end{tabular}

Note: SP Fire 105 is a Swedish full scale test method $[3,4]$ that was developed in the 80 's. It is based on research conducted by SP and Lund University $[5,6]$.

\section{Sweden}

Source: Swedish building regulations of 2011, BBR 19 [7].

\begin{tabular}{|c|c|}
\hline Objective/characteristic & Pre-accepted solution \\
\hline $\begin{array}{l}\text { 1. Protection against fire } \\
\text { spread along the façade }\end{array}$ & $\begin{array}{l}\text { A2-s1,d0 } \\
\text { Certain exceptions allow D-s2,d2, for instance if sprinklers are } \\
\text { installed in the building or only limited areas of the facade. } \\
\text { or } \\
\text { Compliance can be shown by testing with SP Fire } 105\end{array}$ \\
\hline $\begin{array}{l}\text { 2. Maintaining the function of } \\
\text { the fire compartmentation }\end{array}$ & $\begin{array}{l}\text { Risk shall be addressed. In practice this could be a fire } \\
\text { resistance requirement E } 30 \text { or EI } 30\end{array}$ \\
\hline 3. Protection against falling objects & Compliance can be shown by testing with SP Fire 105. \\
\hline $\begin{array}{l}\text { 4. Reaction to fire requirements } \\
\text { for components in the } \\
\text { external wall }\end{array}$ & $\begin{array}{l}\text { A2-s1,d0 } \\
\text { or } \\
\text { Fire stops preventing fire spread required at each floor unless } \\
\text { the whole external wall. } \\
\text { or } \\
\text { Compliance can be shown by testing with SP Fire } 105 \text {. }\end{array}$ \\
\hline $\begin{array}{l}\text { 5. Reaction to fire } \\
\text { for the load-bearing construction } \\
\text { in the external wall }\end{array}$ & $\begin{array}{l}\text { No requirement as long as the requirements loadbearing } \\
\text { capacity is met for stipulated time, i.e. R } 60 \text {. }\end{array}$ \\
\hline $\begin{array}{l}\text { 6. Protection against fire spread } \\
\text { between windows }\end{array}$ & 1,2 $\mathrm{m}$ or windows in E30. \\
\hline
\end{tabular}




\section{MATEC Web of Conferences}

\section{Denmark}

Source: Exsempelsamling om brandsikring af byggeri 2012 [8].

\begin{tabular}{|l|l|}
\hline Objective/characteristic & Pre-accepted solution \\
\hline $\begin{array}{l}\text { 1. Protection against fire spread } \\
\text { along the façade }\end{array}$ & $\begin{array}{l}\text { Covering class K1 10 B-s1, d0 or K1 10 D-s2 } \\
\text { d2 (depending on building height) } \\
\text { Certain exceptions allow D-s2,d2 for lower buildings. } \\
\text { Insulation materials with D-s1,d0 or lower poorer than material } \\
\text { class D-s2,d2 (material level) must be protected with a covering } \\
\text { class K1 10 B-s1, d0 or a construction class EI/REI30 } \\
\text { or a construction class EI/REI30 and A2-s1,d0 } \\
\text { (depending on building height) on each side. }\end{array}$ \\
\hline $\begin{array}{l}\text { 2. Maintaining the function of } \\
\text { the fire compartmentation }\end{array}$ & $\begin{array}{l}\text { The compartmentation (EI 60)must be extended to the inside } \\
\text { of the external façade cladding. }\end{array}$ \\
\hline $\begin{array}{l}\text { 3. Protection against falling } \\
\text { objects }\end{array}$ & No requirements. \\
\hline $\begin{array}{l}\text { 4. Reaction to fire requirements } \\
\text { for components in the } \\
\text { external wall }\end{array}$ & See objective 1 and 2. \\
\hline $\begin{array}{l}\text { 5. Reaction to fire requirements } \\
\text { for the load-bearing construction } \\
\text { in the external wall }\end{array}$ & R60/120 A2-s1,d0 \\
\hline $\begin{array}{l}\text { 6. Protection against fire } \\
\text { spread between windows }\end{array}$ & $\begin{array}{l}\text { The risk should be evaluated if the façade is sloping outwards, } \\
\text { but no distance is regulated }\end{array}$ \\
\hline
\end{tabular}

\section{Norway}

Source: Veiledning om tekniska krav til byggverk [9].

\begin{tabular}{|l|l|}
\hline Objective/characteristic & Pre-accepted solution \\
\hline $\begin{array}{l}\text { 1. Protection against fire } \\
\text { spread along the façade }\end{array}$ & $\begin{array}{l}\text { Cladding of class B-s3,d0. However D-s3,d0 in low rise } \\
\text { buildings (maximum 4 stories, depending on risk class } \\
\text { and hazard class) and if the fire risk in the facade is limited } \\
\text { and the risk of fire spread to other buildings is low. }\end{array}$ \\
\hline $\begin{array}{l}\text { 2. Maintaining the function of } \\
\text { the fire compartmentation }\end{array}$ & $\begin{array}{l}\text { A zone corresponding to the window height must be } \\
\text { protected by E 30 } \\
\text { or } \\
\text { Each other floor E 30 } \\
\text { or } \\
\text { Design of the façade will prevent fire spread } \\
\text { or } \\
\text { Sprinkler (requirement in some types of buildings) }\end{array}$ \\
\hline 3. Protection against & $\begin{array}{l}\text { General requirement.falling objects } \\
\text { Not specifically linked to fire safety. } \\
\text { Regarding external insulation systems for existing buildings: } \\
\text { Compliance can be shown by testing with SP Fire 105 }\end{array}$ \\
\hline $\begin{array}{l}\text { 4. Reaction to fire requirements } \\
\text { for components in the external wall }\end{array}$ & $\begin{array}{l}\text { Insulation must be } \\
\text { of class A2-s1,d0. } \\
\text { External insulation systems for existing building: } \\
\text { Testing according to SP Fire 105. However }\end{array}$ \\
\hline
\end{tabular}




\begin{tabular}{|l|l|}
\hline & $\begin{array}{l}\text { not pre-accepted in hazard class 3 (more than 4 stories) } \\
\text { and risk class 6 (hospitals, hotels etc.) }\end{array}$ \\
\hline $\begin{array}{l}\text { 5. Reaction to fire requirements } \\
\text { for the load-bearing construction } \\
\text { in the external wall }\end{array}$ & $\begin{array}{l}\text { Fire class } 3 \text { buildings with more than four stories): } \\
\text { Load-bearing construction must be A2-s1,d0. }\end{array}$ \\
\hline $\begin{array}{l}\text { 6. Protection against fire } \\
\text { spread between windows }\end{array}$ & Se the zone requirements above. \\
\hline
\end{tabular}

\section{Finland}

Source: E1, Finlands byggbestämmelsesamling (Swedish translation), 2002 [10].

\begin{tabular}{|c|c|}
\hline Objective/characteristic & Pre-accepted solution \\
\hline $\begin{array}{l}\text { 1. Protection against fire } \\
\text { spread along the façade }\end{array}$ & $\begin{array}{l}\text { 3-8 floors (apartment and office buildings): } \\
\text { B-s2,d0 generally and D-s2,d2 if building } \\
\text { sprinklered (excluding first floor) } \\
\text { Higher buildings: B-s1,d0 } \\
\text { +Certain exceptions allow D-s2, d2 for } \\
\text { minor areas }\end{array}$ \\
\hline $\begin{array}{l}\text { 2. Maintaining the function } \\
\text { of the fire compartmentation addressed }\end{array}$ & $\begin{array}{l}\text { Risk of fire spread shall be } \\
\text { Normally no fire separating function of external } \\
\text { wall is required }\end{array}$ \\
\hline $\begin{array}{l}\text { 3. Protection against falling } \\
\text { objects }\end{array}$ & $\begin{array}{l}\text { Applies only when D-s2,d2 class cladding } \\
\text { (wood) is used in 3-8 floor buildings }\end{array}$ \\
\hline $\begin{array}{l}\text { 4. Reaction to fire requirements for } \\
\text { components in the external wall }\end{array}$ & $\begin{array}{l}\text { In designing the constructions of external walls, } \\
\text { the hazard of fire spreading within the construction } \\
\text { and through the joints shall be considered. } \\
\text { P1 class buildings (number of floors: } \\
3 \text { - unlimited): Thermal insulation which is inferior } \\
\text { to class B-s1, d0 shall be protected and positioned } \\
\text { in such a manner that the spread of fire } \\
\text { into the insulation, from one fire compartment } \\
\text { to another and from one building to another } \\
\text { building is prevented. In these cases } \\
\text { rendering or a metal sheet is generally not a } \\
\text { sufficient protection. } \\
\text { Protected combustible insulation can be } \\
\text { allowed in certain cases. For example coverings } \\
\text { fulfilling fire resistance EI } 30 \text { or large scale } \\
\text { or some experimental/calculation } \\
\text { evidence on protective performance/ } \\
\text { no contribution to fire spread. A2-s1,d0 or B-s2, } \\
\text { d0 if the load bearing construction is } \\
\text { combustible (buildings with 3-8 floors). }\end{array}$ \\
\hline $\begin{array}{l}\text { 5. Reaction to fire requirements for } \\
\text { the load-bearing construction } \\
\text { in the external wall }\end{array}$ & $\begin{array}{l}\text { K2 } 10 \text { covering for timber framed building } \\
\text { with 3-4 floors and K2 } 30 \text { covering for } \\
\text { timber framed building with 3-4 floors }\end{array}$ \\
\hline $\begin{array}{l}\text { 6. Protection against fire } \\
\text { spread between windows }\end{array}$ & No requirements. \\
\hline
\end{tabular}




\section{MATEC Web of Conferences}

\section{ANALYSIS}

There are few requirements for facades in the Nordic countries that are in common. Each set of requirements or deemed-to-satisfy solutions may be considered as being country-specific. For each of the objectives, a categorization and summary is made below.

1. Protection against fire spread along the façade

Acceptable solutions vary from non-combustible material (A2-s1,d0) to only fulfilling variation $\mathrm{s}$ of Euroclass B. In Sweden, full-scale testing is also accepted as an alternative. Some countries allow some parts of the façade to be of a lower class, i.e. D-s2,d0.

2. Maintaining the function of the fire compartmentation

All countries except Finland accept some form of fire resistance as an acceptable solution. However, assessments must be done in Finland. This is to a large degree also true for Sweden, where the level of fire resistance is not explicitly stated.

3. Protection against falling objects

Only Sweden and Norway has explicit requirements against falling objects. It may however apply in Denmark and Finland as well in certain situations. The acceptable solutions in Sweden and Norway may either be based on assessment or by full scale testing, depending on the situation.

4. Reaction to fire requirements for components in the external wall

Usually, non-combustible material (A2-s1,d0) is accepted. Combustible insulation in Finland and Denmark must either be protected by fire resistant enclosure or fire protected cladding. Sweden accepts either fire stops at each floor, or full scale testing - which Norway also accepts in certain situations. Finland also requires the hazard of fire spread at joints to be considered.

5. Reaction to fire requirements for the load-bearing construction in the external wall

All countries except Sweden require non-combustible load-bearing structures in certain situations. This is usually height-dependent and it may be possible to use fire protected cladding in certain situations. The exact regulation varies between the countries. It should be noted that large amounts of combustible material in a building sometimes may require, or coincide with the use of fire safety engineering methods.

6. Protection against fire spread between windows

Separation distance between windows is only explicitly required in Sweden, Norway has special requirements that is connected to fire resistance solutions. Finland has no requirements whereas Denmark requires a risk evaluation if the façade is sloping.

\section{EU-legislation and common test methods}

As demonstrated in the study of Nordic regulations there are a lot of different performance criteria that has to be dealt with regarding fire safety and facades.

In EU harmonized standards and test methods are available for reaction to fire and resistance to fire since a couple of years. However there are big uncertainties when applying them to facades.

\section{Reaction to fire}

The reaction to fire classes for building products according to the European classification with the so called Euroclasses, i.e. B-s1,d0 and similar, may be unsuitable to represent façade fire behaviour since they are developed to represent the behaviour of materials in walls and ceiling linked to the phenomena of flashover in a small room. For instance Euroclass B means that no flashover will occur in the room corner test [11] with an ignition source of $300 \mathrm{~kW}$.

However, when it comes to facades and preventing vertical fire spread the starting point is that flashover already has occurred. The ignition source will in that case often be a room fire and a flame through a window with a completely different fire scenario than the Euroclasses were developed for. 
The whole basis and theoretical background for the Euroclasses is therefore to a large degree not valid for facades.

Using the Euroclasses may therefore have little or no correlation with the fire safety objectives you are trying to regulate. Even so the Euroclasses are used in the Nordic countries in lack of other options.

\section{Resistance to fire}

For some façade requirements in the Nordic countries, the European classes for resistance to fire are used [12]. How the facade should be classified when it comes to resistance to fire is a delicate question. The objective is not to prevent the fire from penetrating the facade, but to keep the fire compartmentation between different stories in the building intact. It is therefore not certain that a specific resistance to fire class should be regulated to fulfil the demand of stop fire spread along the facade. This is also demonstrated by the fact that resistance to fire class isn't always required in the studied regulations.

Another problem is that fire resistance is measured with thermocouples and the cotton pad test. As long as these criteria are fulfilled the test doesn't take into account if big objects will fall from the construction. It will also not measure the fire spread inside the facade as long as the compartmentation between two floors are fulfilled.

\section{Lack of full scale test methods}

Both the test methods and objectives for reaction to fire and resistance to fire are not developed to address the problems with facades. To regulate the fire behaviour for facades some extra functional requirements or full scale testing of the facade is needed.

The lack of a European test method for facades has therefore resulted in that different countries has very different regulations and requirements for specific full scale test in certain cases. There also exist CE-marked products, where the standards do not reflect the requirements in the Nordic countries. For example, the Swedish requirement to prevent falling objects is not reflected in EN 13830 - Curtain walling [13].

\section{DISCUSSION}

From a practical point of view in Sweden, there are several problems concerning verification of façade requirements. In Sweden today the facades built in many projects have little formal connection to the requirements in the building regulations due to the lack of applicable test methods in certain aspects. There are uncertainties with regards to requirements of falling objects and how this should be verified when not using full-scale methods. Also, the full-scale methods may not reflect the behavior of modern facades. There are also uncertainties regarding how prevention of fire spread within the external wall should be verified. Due to this, questions regarding fire safety and facades risks get too little attention and low priority in building projects.

SP Fire 105 which is the full scale test method used in Sweden focuses on fire exposure on the outside of a façade from a flame out from a window. The method mainly answers the question whether the façade surface cladding or insulation increases the risk of fire vertical fire spread. The test also includes an assessment of the risk of falling objects. In practice, most facades that are tested by SP Fire 105 on the Swedish market are facades with combustible surface cladding or facades with combustible insulation, for example wood with some added fire protection or facades insulated with EPS.

The effect of the requirements and current practice is that the structural integrity and response to fire of a non-load bearing façades are not assessed fully with regards to fire risks. For non-combustible facades few assessments are made concerning structural integrity and for façade elements that has been tested by the only available test method no one knows what happens when the façade is subjected to a 


\section{MATEC Web of Conferences}

fully developed room fire from the inside - rather than an external flame on the outside coming from a window.

\section{CONCLUSIONS}

There is a great need for development of new verification systems for façade systems. The existing European classification systems are not sufficient to describe or represent the characteristics of modern façade systems. The different requirements in the Nordic countries also show that it is a complex issue. While the fire risks and building traditions in the Nordic countries probably are quite similar, this is not reflected in how the fire safety requirements for facades are expressed. As stated in previous Nordic harmonization work, the way forward is to develop new method in the European system that reflects the actual fire risks of facades. It is important to address that façade system design, and envelope design of buildings in general, has changed significantly in the last decades. Several large or full scale test methods for facades exists which could be evaluated and serve as a basis for the development of new verification methods. Since there are uncertainties both regarding the actual fire safety objectives of façades and suitable pre-accepted solutions, it will be important to identify and analyze the fire risks, for example based on fire statistics and case-studies of fire incidents. In the current practice, with uncertainties in objectives and acceptable solutions, it is vital to make assessments of the façade fire safety from a holistic perspective. This is especially true for modern façade systems.

Anders Dragsted, the Danish Institute of Fire and Security Technology (DBI) Esko Mikkola, KK-Palokonsultti Vidar Stenstad, Direktoratet for byggkvalitet.

\section{References}

[1] The European Parliament and of the Council, Regulation (EU) No 305/2011 of the European Parliament and of the Council of 9 March 2011 laying down harmonised conditions for the marketing of construction products and repealing Council Directive 89/106/EEC. 2011, the European Parliament and of the Council: EU.

[2] Thureson, P., et al., The use of fire classification in the Nordic countries - Proposals for harmonisation. 2008, SP Technical Research Institute of Sweden.

[3] Swedish National Testing and Research Institute, SP Fire 105 - External Wall Assemblies and Facade Claddings - Reaction to Fire - Issue No: 5. 1994.

[4] Swedish National Testing and Research Institute, SP Fire 105 - Method for fire testing of facade materials, Dnr 171-79-360. 1985.

[5] Ondrus, J., Fire Hazards of Facades with Externally Applied Thermal Insulation. 1985, Lund Institute of Technology.

[6] Ondrus, J. and O. Pettersson, Brandrisker utvändigt isolerade fasader. 1986.

[7] Boverket, Boverkets byggregler, BBR 19, (föreskrifter och allmänna råd), BFS 2011-6 med ändringar t.o.m. BFS 2011-26). 2011.

[8] Energistyrelsen, Eksempelsamling om brandsikring af byggeri 2012. 2012.

[9] Direktoratet for byggkvalitet, Veiledning om tekniska krav till byggverk (downloaded 2012-10-12). 2012.

[10] Minister of the Environment, E1 The National Building Code of FInland - Fire safety of buildings - Regulations and guidelines. 2002. 
$1^{\text {st }}$ International Seminar for Fire Safety of Facades, Paris (France), 2013

[11] International Organization for Standardization, ISO 9705 - Fire tests - Full-scale room tests for surface products. 2000.

[12] European Committee for Standardization, EN 13501-2:2007 Fire classification of construction products and building elements - Part 2: Classification using data from fire resistance tests, excluding ventilation services. 2007.

[13] Swedish Standards Institute, SS-EN 13830 Curtain walling - Product Standard. 2003. 